Copyright (C) 2019 by Academic Publishing House Researcher

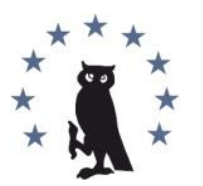

Published in the Russian Federation

European Researcher. Series A

Has been issued since 2010.

E-ISSN 2224-0136

2019, 10(2): 110-124

DOI: $10.13187 / \mathrm{er} .2019 \cdot 2.110$

www.erjournal.ru

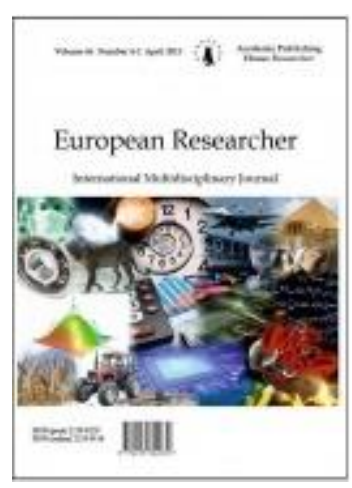

\title{
Hermeneutic Analysis of German-Language Audiovisual Texts on School Theme (1945-2018)
}

\author{
Anastasia Levitskaya a ${ }^{a}$, Lyudmila Seliverstova a \\ a Taganrog Management and Economics Institute, Russian Federation
}

\begin{abstract}
The article is devoted to the analysis of German-language audiovisual media texts on school theme that were screened in Germany from the end of the Second World War to the present time by a method of comparative hermeneutic analysis. The analysis let find out that in the post-war period filmmakers sought to improve the social climate in society, to return to the pedagogical traditions of the Weimar Republic, to create a desired ideal image of student-teacher relationships, and tried to smooth the acute problems of the generation growing up in the post-war defeated Germany. An ideal teacher was portrayed as an adult that children can trust.

In the period of the divided Germany, films about school reflected sensitive social challenges: misunderstanding of generations (parents vs. children), the search for opportunities to atone for the Nazi past for crimes against humanity through their recognition and condemnation. In films, rebellious moods were shown both in relation to authoritarian pedagogy and hypocritical sexual morality.

Modern German cinema clearly communicates young people's mindset to search self, to identify one's place in life and society. Teachers are depicted as people above all, human beings with their personal worries and aspirations, experiencing moments of success and failure.

Keywords: hermeneutics, analysis, media text, media criticism, film, schoolchildren, media literacy, media education, Germany.

\section{1. Введение}

В современном мире глобальных информационных процессов кинематограф занимает особое место. На киноэкране отражаются доминирующие в обществе ценности и нормы. В ходе работы над фильмами кинематографисты преломляют общественные реалии через призму собственного восприятия и посредством художественных образов формируют сознание социума. Рассмотрение отдельных фильмов с точки зрения отражения и формирования в них образцов и моделей поведения, характерных для общества на определенном этапе его развития, позволяет получить некое представление о мироустройстве. Неделимость анализа киноискусства и мироустройства подчеркивают отечественные и зарубежные специалисты (Гожанская, 2006; Мкртычева, 2012; Mai, Winter, 2006). Кинофильмы всегда несут в себе отпечаток социальных конфликтов и противоречий (Mai, Winter, 2006: 106), благодаря этому ученые могут многое узнать о социальной и культурной
\end{abstract}

\footnotetext{
${ }^{*}$ Corresponding author

E-mail addresses: a.levitskaya@tmei.ru (A. Levitskaya), l.seliverstova@tmei.ru (L. Seliverstova)
} 
жизни общества, значительная часть которой отведена образованию. В этой связи представляется интересным рассмотреть тему школы в немецкоязычных игровых фильмах.

\section{2. Материалы и методы}

Такой многогранный предмет как кино настраивает ученых на поиск комплексной теории, на использование при его анализе всего богатства теоретико-методологических подходов. В качестве основного метода настоящего исследования использован сравнительный герменевтический анализ немецкоязычных аудиовизуальных медиатекстов (1946-2018), касающихся данной тематики (включая: анализ стереотипов, идеологический анализ, идентификационный анализ, иконографический анализ и др.). В процессе анализа мы опирались на методологию А.В. Федорова (Федоров, 2007, 2013) и на такие ключевые аспекты медиаобразования как «медийные агентства» (media agencies), «категории медиа/медиатекстов» (media/media text categories), «медийные технологии» (media technologies), «языки медиа» (media languages), «медийные репрезентации» (media representations) и «медийная аудитория» (media audiences), так как все эти понятия имеют непосредственное отношение к герменевтическому анализу медиатекстов.

Материалом исследования послужили немецкоязычные аудиовизуальные медиатексты, а именно, игровые фильмы на школьную тематику послевоенной Германии, разделенной Германии и объединенной Германии. Предпринятая попытка далеко не первая. Так, Фридрих Кох методом качественного герменевтического анализа исследовал немецкие фильмы о школе, а именно, как в них отражены проблемы власти и подчинения в процессе воспитания и обучения (Koch, 1987). Специалисты в сфере медиа и литературоведы Фленсбургского университета Г. Хелмес и Г. Ринке анализировали современную картину школы и образ учителя в литературных произведениях и кинофильмах Федеративной республики (Helmes, Rinke, 2016).

\section{3. Обсуждение}

Игровые фильмы были условно разделены на три периода:

- фильмы послевоенной эпохи (1945-1960);

- фильмы периода «холодной войны» (разделенной Германии) (1961-1989);

- фильмы объединенной Германии (1990-2018).

После падения фашистской Германии производство, прокат и показ кинофильмов во всех зонах оккупации на территории страны был запрещен. Исключение было возможно только при наличии лицензии на данные виды деятельности, которую можно было получить в органах информационного контроля (Nachrichtenkontrollbehörde) при условии непричастности к НСДАП. Таким образом, практически все кинематографисты, работавшие в стране в период существования национал-социалистического режима, были лишены возможности трудиться в киноиндустрии, поскольку членство в партии было обязательным условием профессиональной деятельности в нацистской Германии.

Киноиндустрия в советской зоне оккупации и западных зонах развивалась самостоятельно. В Бабельсберге в советской зоне были сосредоточены основные мощности довоенного немецкого кинопроизводства, которое было национализировано и сосредоточено вокруг студии DEFA. В западной зоне был запущен процесс декартелизации, основной целью которого было создание нового, непропагандистского кино. Кинематографическими центрами стали Мюнхен и Гамбург (Brockmann, 2010: 186).

В послевоенные годы основной темой кинофильмов было осмысление катастрофы, постигшей Германию, и преодоление нацистского прошлого, что нашло отражение в так называемом «руинном кино» («Trümmerfilm»). В восточной зоне кинематографисты DEFA стремились отрефлексировать причины появления нацизма, а в западной зоне снимались фильмы, в первую очередь направленные в будущее, рисовавшие картины возрождения мирной жизни и не задававшие самых неудобных вопросов (Brockmann, 2010: 194-196). В западной зоне в послевоенный период снимались в основном фильмы в жанре так называемого «кино о Родине» («Heimatfilme»), воспевавшие жизнь, близкую к природе, дружбу и семейные ценности. 
Об активном развитии киноиндустрии в послевоенной Германии говорить не приходится в силу объективных политических и экономических причин. Так, в британском журнале «Sight \& Sound» Германия 1950-х была названа «кинематографической пустыней» (цит. по: Watson, 1996: 29). Тема учебы и обучения долгое время не поднималась (Roschy, 2008), однако, это не означает, что фильмов на школьную тематику не было вовсе. Послевоенная «общая тенденция стремления к восстановлению» (Koch, 1987: 159) выразилась в работе немецких кинематографистов над римейками фильмов о школе: «Учитель Уве Карстен из Хайде» / «Heideschulmeister Uwe Karsten» (1932/1954), «Взрослеющая молодежь» / «Reifende Jugend» (1931/1955), «Девушки в униформе» / «Mädchen in Uniform» (1931/1958) и др. Как отмечают специалисты, ни в одно другое десятилетие истории немецкого кино в целом не снималось так много ремейков, как в 1950-е годы (Frank, 2017: 495).

Фридрих Кох утверждает, что в эпоху канцлера К. Аденауэра разрыва с националсоциалистическим прошлым в кино так и не произошло. Многие фильмы послевоенного периода пропагандировали общественные отношения, характерные для авторитарного нацистского режима. В середине 1950-х на киноэкране вновь ожили истории, в которых культивировался авторитет вождя и рисовался образ «чистой» с точки зрения националсоциалистической доктрины молодежи. Речь идет об одноименном римейке (1955) кинофильма «Взрослеющая молодежь» (1931). При этом Ф. Кох дает невысокую оценку режиссерской работе У. Эрфурта, а произведение в целом считает сомнительным. Исследователь не скрывает недоумения относительно того, что фильм снят так, как будто ничего не произошло, и в Германии все осталось по-прежнему (Koch, 1987: 157-161).

Противоположной точки зрения придерживается Ш. Франк: «Уже начало фильма «Взрослеющая молодежь» указывает на то, что представляется послевоенное время. Широко обсуждается отношение учителей к молодежи и защитная педагогика, с одной стороны, а, с другой, вера в молодежь. Подробно разбирается конфликт поколений. «Капитан», авторитарный учитель истории в ленте 1933 года, в версии 1955 года становится чувствительным учителем греческого языка, который, однако, наказывает оплеухой строптивого ученика. Характеристики молодых людей переосмысливаются, им предстоит разрешить широкий спектр конфликтов, в том числе поднимается проблема сексуальности, связанная в новой версии фильма с молодежной и медиакультурой 1950-Х» (Frank, 2017: 19-20).

Несмотря на расхождения во мнениях специалистов относительно репрезентаций общественных реалий, несомненен факт кардинальных изменений восприятия кинематографа зрителями, и в первую очередь - молодежью. По окончании войны молодые люди лишились веры в авторитеты, иллюзий относительно величия Третьего рейха, что не могло не выразиться в скептическом отношении ко всему, отчуждении в отношениях со старшим поколением. Молодежь Германии послевоенной эпохи социологи охарактеризовали как «поколение скептиков» (Schelsky, 1957). Скептицизм противоречив по своей природе, одних он побуждает к углубленному поиску истины, а других к воинствующему невежеству и противоборству общественной морали.

Тема противоборствующей молодежи поднимается в трагикомедии Акселя фон Амбессера «Догматик» / «Paucker» (1958) с Х. Рюманном в главной роли. Как утверждают киноведы, несмотря на то, что Рюманн пользовался большой популярностью в нацистской Германии, в абсолютном большинстве картины с его участием «были свободны от пропагандистских концептов и ... посвящены классическим сюжетам - проблемам соотношения личности и общества, духовным исканиям, внутреннему миру «маленького человека», претерпевающего качественную идейно-мировоззренческую трансформацию ... под влиянием внешних обстоятельств, «вызовов времени», выступающих необходимым стимулом, приводящим к побуждению ранее неведомых самому носителю способностей и возможностей» (Юдин, 2017: 27). Проблема «маленького человека» положена в основу сюжета вышеупомянутого фильма «Догматик» (Körner, 2001: 123).

Учитель истории в средней школе небольшого провинциального городка Зайдель, способный «вышколить» любого самого слабого ученика, переезжает в большой город для работы в мужской гимназии и получает руководство в классе, ученики которого дерутся, курят, гоняют на мотоциклах, не признают никаких авторитетов. Вскоре Герман Зайдель убеждается в том, что его традиционные методы воспитания в отношении этих подростков 
не действуют. Осознание того, что ученики «сильнее, выше и лучше» учителя, заставляет его самого меняться в попытках изменить подростков. Застав своего ученика за кражей, педагог дал парню взаймы деньги и помог устроиться на работу, тем самым показал, что деньги всегда можно заработать честным путем. Однако этот путь противоречил интересам главаря банды, хулигана Ледерманна, бросившего школу и выступавшего против любого существующего порядка. Учитель Зайдель вступил в борьбу за своего ученика Петера Клауса и поставил его перед выбором: членство в клубе избранных улицей или успешное окончание гимназии и возможность поступления в университет. Юноша сделал выбор в пользу педагога, за что последнему пришлось поплатиться и ввязаться в драку. В драке Зайдель потерпел поражение, однако, в сражении за своего ученика и класс в целом одержал победу. Демонстративное неуважение со стороны гимназистов сменилось почитанием. Старомодный догматик и сверхстрогий моралист Зайдель, для которого важнейшими качествами ученика были дисциплинированность и послушание, а визитной карточкой класса - умение вставать и садиться, превратился в понимающего наставника - настоящего учителя. Ф. Кох приводит эту киноленту в качестве «образца персонализации социальных проблем», панацеей от которых стала выдающаяся личность педагога (Koch, 1989: 174).

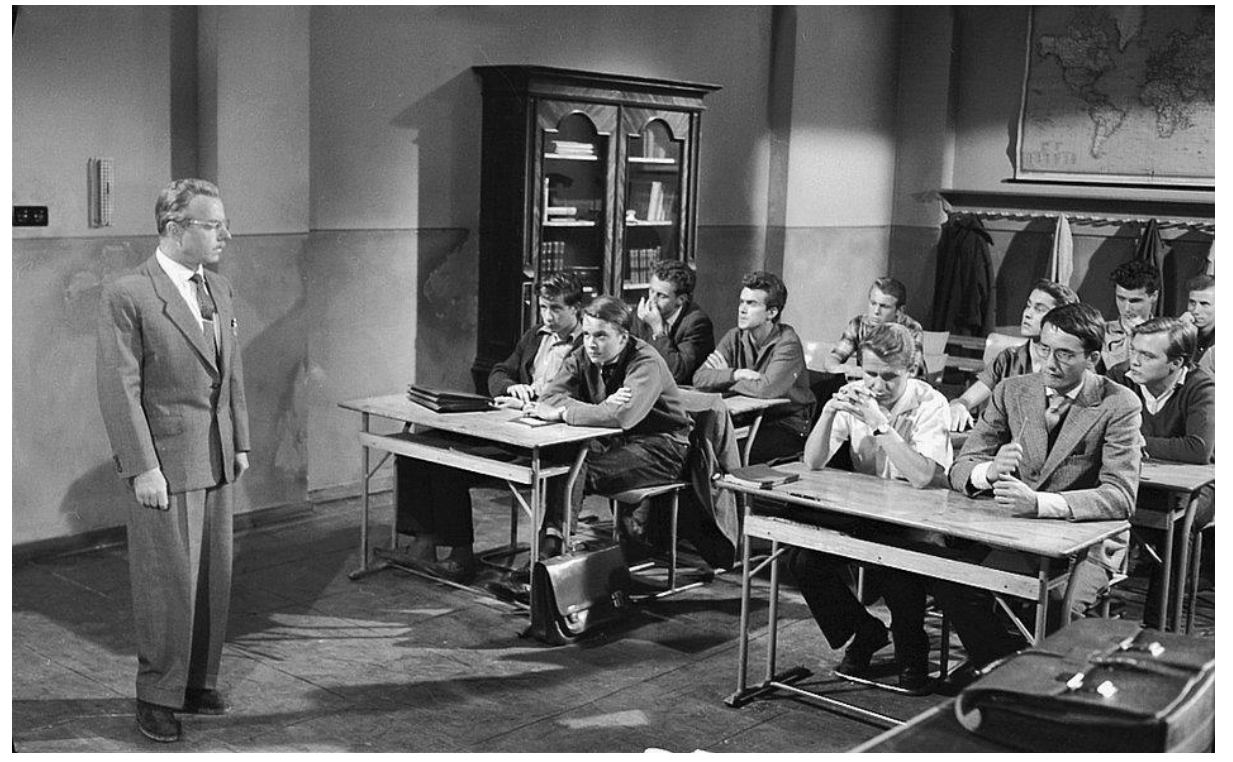

Рис. 1. Кадр из фильма «Догматик» (1958)

Идеализируется образ учителя и в фильме «Летающий класс» / «Das fliegende Klassenzimmer» (1954) К. Хофманна. Учитель географии Берг, которого ученики, любя, называют Юстус, пользуется не только уважением, но и бесконечным доверием у ребят, учащихся мужской гимназии-интерната. Гимназисты - озорные, смешливые мальчишки лазают через стену, катаются на коньках, гоняют мяч в коридоре, шумят, дерутся. Однако следует отметить, это не жестокие драки, а скорее дуэль, выстроенная на принципах порядочности и достоинства: «с врунами не дерутся, их только презирают...». Взросление происходит в дружеской атмосфере, эмоционально и эстетически комфортной - учитель с улыбкой треплет мальчика по вихрам, присаживается на парту лицом к учащимся, сокращая тем самым дистанцию между собой и учениками, приветствует вопросы и активно участвует в спорах, желает им перед сном «спокойной ночи, негодники». 


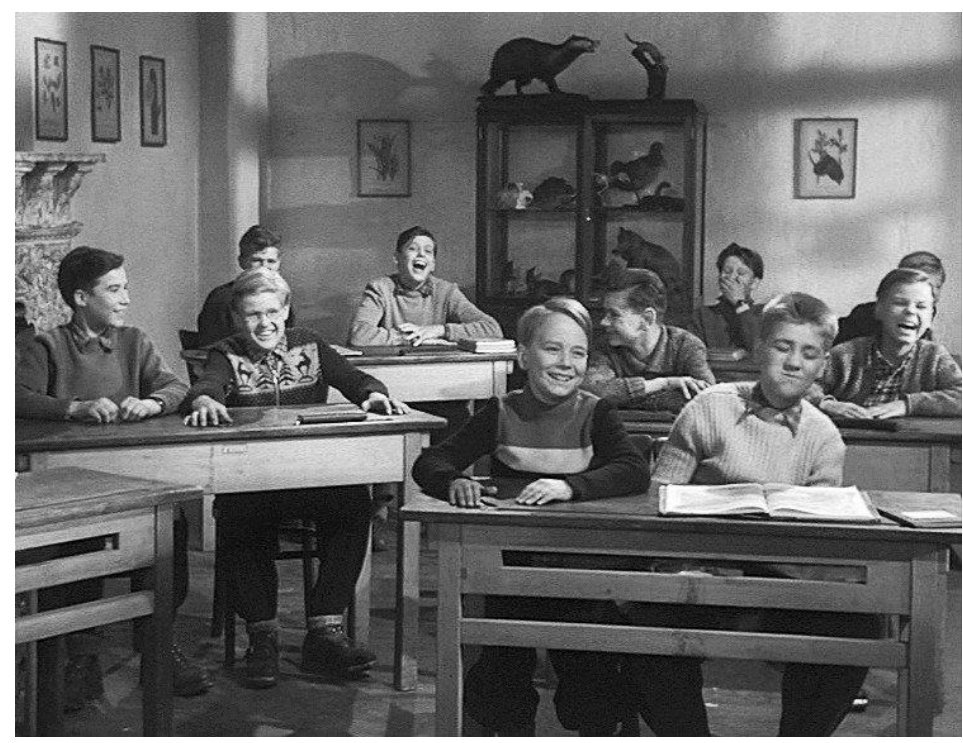

Рис. 2. Кадр из фильма «Летающий класс» (1954)

В тоже время медсестра обращается к гимназистам на Вы, подчеркнуто вежливо. Здание школы представляет собой уютное четырехэтажное строение с многоуровневой крышей с башенками. В классе парты стоят полукругом, на окнах цветы, камин, глобус, чучела животных в шкафу, на дверях узоры с завитушками. В процессе воспитания демонстрируются принципы так называемой «ненавязчивой» педагогики («unaufdringliche» Pädagogik), суть которой в том, чтобы сориентировать и поддержать учащегося, но не навязывать определенные модели мышления и поведения (Piroth, 2004: 295). В качестве наказания за нарушение порядка в гимназии мальчиков на час оставили после занятий, в течение которого учитель Юстус поведал им историю о настоящей дружбе и о себе трудолюбивом мальчике, решившем «стать учителем в этой школе, чтобы другим мальчишкам было с кем делиться тем, что для них важно». В этом фильме, как и в ряде других, главное качество педагога - умение заслужить доверие детей (к этому стремятся классная дама фон Бернбург в фильме «Девушки в униформе» (1958), и учитель физики и математики Ханна Буркхардт в картине «Каждый раз с началом дня» / «Immer wenn der Tag beginnt» (1957).

Начало 1960-х ознаменовало рождение так называемого «Нового немецкого кино» («Der Neue deutsche Film»), авторами которого были режиссеры, родившиеся в годы войны и прошедшие этапы взросления в разделенной Германии. Эти кинематографисты стремились уйти от развлекательного кино к созданию остросоциального, вскрывающего проблемы современного на тот период времени германского общества. Так, в фильме «Молодой Тёрлесс» / «Der junge Törless» (1966) режиссер Ф. Шлендорф ищет ответ на вопрос, является ли пассивный наблюдатель соучастником преступления? Экранизация романа Р. Музиля о садистских увлечениях воспитанников элитной школы напоминала аудитории о недавнем нацистском прошлом (Knight, 2007: 6). Главный герой картины Томас Тёрлесс, воспитанник закрытой школы для мальчиков, знал о том, что его одноклассники жестоко издеваются над Базини, пойманным на краже, но ничего не предпринял, чтобы тому воспрепятствовать. Мало того, он с интересом наблюдал за происходящим и вел записи своих наблюдений, проводил «исследование», задаваясь вопросом «что происходит, когда кого-то мучают и унижают». Жертва же добровольно принимала унижения и издевательства. Автор фильма акцентирует внимание на «психологических и групповых динамических процессах, а также связывает характерные реалии с тоталитарными общественными формами» (Wunderlich). Истоки нацизма $\Phi$. Шлендорф видел в природе детского насилия поколения детей начала XX века.

Отношение к «Новому немецкому кино» в период его расцвета, в том числе и на школьную тематику, было неоднозначным. Одни подчеркивали его особую значимость (Сумароков, 2017), другие обвиняли, например, П. Лилиенталя, автора фильма «Завуч 
Хофер» / «Hauptlehrer Hofer» (1975), в подмене реализма бесчувственностью, точности излишней детализацией, характеризовали работы Ф. Шлендорфа и др. как «безнадежно посредственное, самодовольное зомби-кино» (Blumenberg, 1975). Через шесть лет Х.-К. Блюменберг написал о режиссерах-представителях немецкого авторского кино, что ему «нравятся свобода и наглость одиночек в фильме «На такси до туалета» / «Im Taxi zum Klo» (1980) ... и заумном детективе «Отстранённый от дел» / «Kaltgestellt» (1980)» (Блюменберг, 1981).

В чем угодно, но только не в посредственности и отсутствии темперамента, можно обвинить фильм П. Цадека «Я слон, мадам» / «Ich bin ein Elefant, Madame» (1969), действие которого происходит в конце 1960-х в Бременской школе, где выпускники пытаются противостоять учителям и в их лице - авторитарной педагогике. Этот фильм - не обычная экранизация романа, в нем смешиваются документальные и игровые элементы, показан мятеж детей против учителей как метафора борьбы культур. Режиссер демонстрирует конфликт поколений, в котором забытая в прошлом Германия препятствует стремлению молодежи к свободе и прогрессу (Graff, 2010).

Тема возможности и оправданности «господства одних людей над другими» красной нитью проходит сквозь историю немецкого кино всех периодов, начиная с послевоенного, и не оставляет умы современных кинематографистов. В фильме «Волна» / «Die Welle» (2008) Д. Гензеля немецкие школьники обсуждают социальные условия, ведущие к тоталитаризму, и задаются вопросом: возможна ли в Германии диктатура? Будучи абсолютно уверенными в том, что «диктатура в Германии больше не возможна, мы для этого слишком умные», школьники добровольно становятся участниками эксперимента, в результате которого получают однозначный положительный ответ: да, возможна. Главный герой фильма учитель физкультуры Венгер, пользующийся доверием и уважением со стороны гимназистов, очень демократичный, позволяющий обращаться к себе на «ты», в черной рокерской футболке, с татуировкой и коротко стриженый - своего рода антипод стереотипному представлению об учителе, затянутом в костюм и галстук. В течение нескольких дней учитель Венгер с помощью «фашистских штучек» заполнил «вакуум в жизни подростков» (Probst, 2008) - удовлетворил их потребность быть частью определенного общества, где тебя принимают таким, какой ты есть, и оказывают поддержку. Первым делом Венгер предложил себя в качестве лидера и обозначил свою главенствующую роль тем, что члены группы должны были к нему обращаться «господин Венгер». Далее претворил в жизнь принцип «власть через дисциплину», четко обозначив правила игры, кто их не соблюдает, должен уйти. Нет места инакомыслию. Затем он рассадил слабых по успеваемости школьников с более сильными и предложил всем переодеться в одинаковые белые майки. Униформа нивелирует социальные различия и индивидуальность, помогает определить «своих» среди «прочих». Дополнив все это общей символикой и приветствием, шаг за шагом учитель создал свое тоталитарное общество. Жертв избежать не удалось, ими стали сам заигравшийся учитель, фанатично преданный своему господину Венгеру гимназист и застреленный им одноклассник. В одном из заключительных кадров крупным планом показано лицо учителя - лицо всей Германии, вдруг очнувшейся от осознания ужаса совершенного в годы войны. Устами одного из героев - подростка турецкого происхождения - зрителю доносится еще одна очень важная мысль о том, что нельзя жить лишь осознанием вины, что нужно «позволить немцам гордиться своей страной, в противном случае это вернется бумерангом, и они возненавидят других». Этот фильм показывает стремление немецких кинематографистов еще раз осмыслить причины и последствия национальной трагедии. 


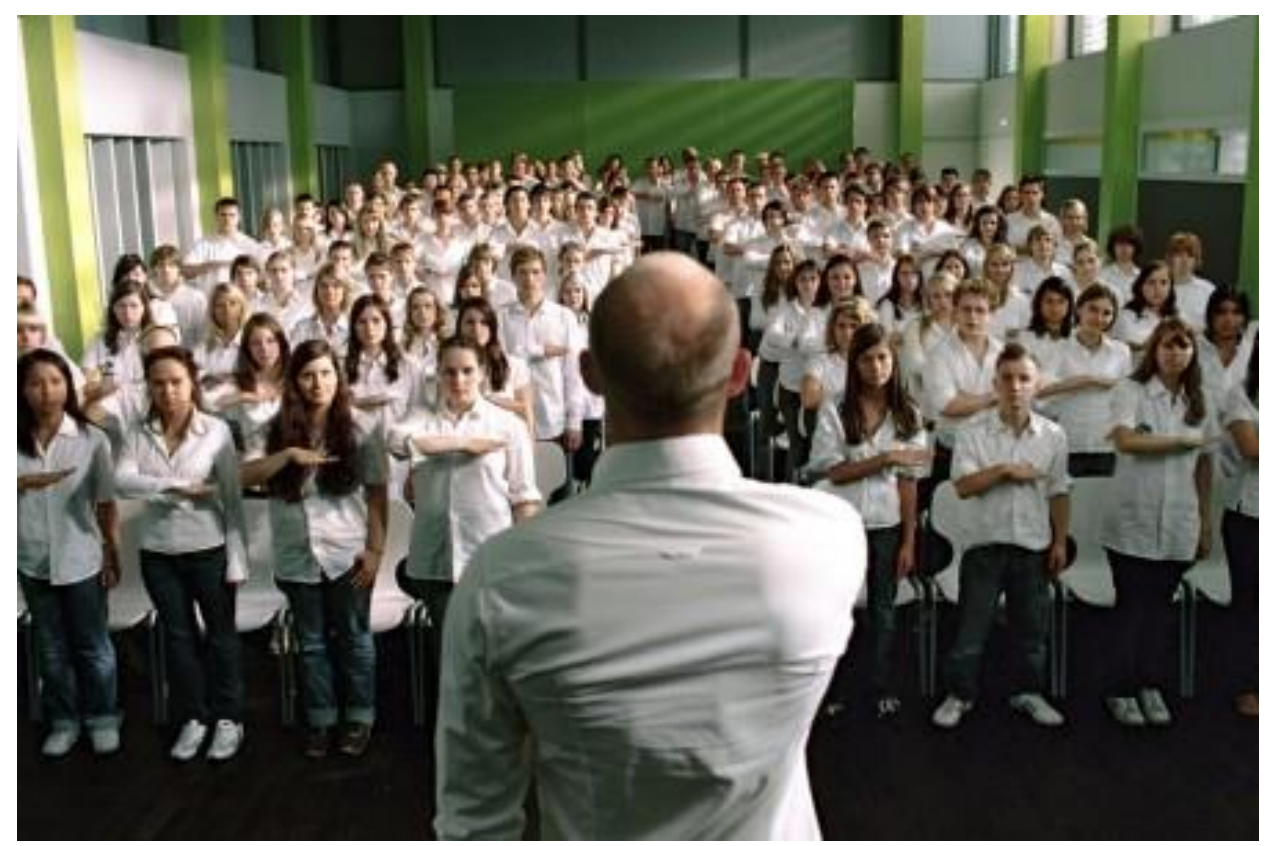

Рис. 3. Кадр из фильма «Волна» (2008)

Фильм «Волна» (2008) вошел в 25 лучших фильмов о школе согласно рейтингу немецкого молодежного журнала UNICUM (abi.unicum.de) наравне с картинами «Огненные клещи» / «Feuerzangenbowle» $(1944,1970)$; «Летающий класс» (1954, 1973, 2003); «Доброе утро, господин Гроте» / «Guten Morgen, Herr Grote» (2007); «Йонас» / «Jonas» (2012) и «Зачетный препод» / «Fack ju Göthe» (2013, 2015 и 2017). Особую популярность среди телезрителей приобрели сериалы «Наш учитель доктор Шпехт» / «Unser Lehrer Doktor Specht» (1990) на канале ZDF и «Учитель» / «Der Lehrer» (2012) на канале RTL.

Главный герой фильма Л. Крауме «Доброе утро, господин Гроте» (2007) - 37-летний Михаэль Гроте, учитель немецкого языка обычной берлинской гимназии - предан своей профессии, работа и проблемы школьников занимают все его время, в связи с этим не складывается личная жизнь. Он не оставляет попытки помочь своему ученику Нико, фрустрированному агрессивному подростку, в то время как остальные коллеги давно перевели его в разряд необучаемых. Нико не единственный сложный ученик класса, многие из ребят живут в социально неблагополучных семьях, в семьях мигрантов из других стран и пр. Учитель Гроте - противоречивый персонаж, предъявляющий по отношению к себе как педагогу чрезмерно высокие требования и в тоже время безответственный отец. Он все силы отдает ученику Нико, а собственный сын в это время воспитывается в его отсутствие. Картина была удостоена премии А. Гримма (2008) и была высоко оценена жюри: «Фильм не дает несбыточных надежд, но в тоже время не анонсирует полную безнадежность немецкой системы школьного образования» (Grimme 2008). 


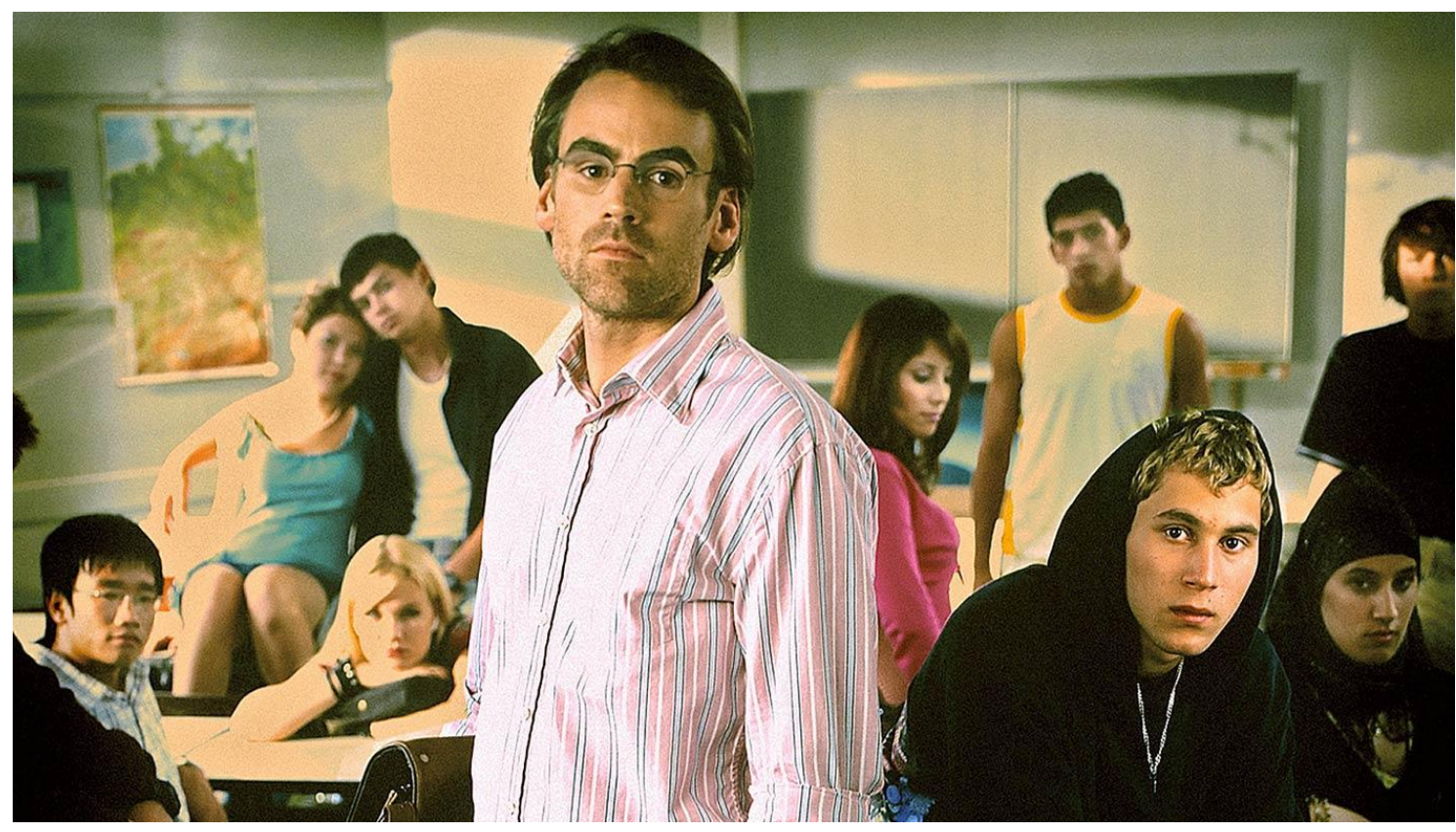

Рис. 4. Кадр из фильма «Доброе утро, господин Гроте» (2007)

Если в фильме Л. Крауме учитель Гроте в жертву профессии принес свою личную жизнь, то в драме Т. Трагезера «Учительница» / «Lehrerin» (2011) жертвой вооруженной агрессии школьника стала молодая учительница Катя Шлепер, получившая тяжелое ранение, а с ней вместе тяжелую психологическую травму получили 25 учеников ее класса и педагогический коллектив школы. Класс Кати берет под руководство ее подруга, учитель биологии Андреа Либнитц, которая пытается помочь детям справиться с непростой жизненной ситуацией. В день трагедии Андреа собиралась подать заявление об увольнении и поставить точку в своей педагогической карьере, однако, выгорев за 13 лет работы в школе, героиня фильма как Феникс возродилась в профессии и вместе с учениками класса вернулась к нормальной жизни.

В роли жертвы представлен учитель и в картине Грегора Шнитцлера «Инстинкт игрока» / «Spieltrieb» (2013). Главные герои фильма 15-летняя Ада и совершеннолетний Алев затевают игру «Познай самого себя» с учителем физкультуры и немецкого языка Смутеком. Манипулятор и интриган Алев подбивает интеллектуально очень одаренную и от того одинокую одноклассницу соблазнить учителя с целью шантажа. Подросткам не нужен шантаж ради шантажа, они хотят «освободить» учителя и «сделать его счастливым», «дать ему шанс освободиться от оков старой жизни или окончательно ее разрушить». Игра выходит из под контроля, и все ее участники оказываются в зале суда. Автор фильма в своей картине размышляет над весьма актуальным в современном мире вопросом о том, можно ли «навязать» свободу вопреки желанию.

В числе немецких фильмов на школьную тематику, представляющих интерес, следует отметить также работы «Конференция» / «Die Konferenz» (2004) Н. Штейн и «Фрау Мюллер должна уйти» / «Frau Müller muss weg» (2015) 3. Вортманна. В обеих картинах место действия - замкнутое пространство школы. В фильме Н. Штейн в зале школьной библиотеки холодным зимним вечером собираются девять педагогов, чтобы решить судьбу Виктора Лейзена, обвиняемого в попытке изнасилования 17-летней одноклассницы. Вскоре с основного предмета обсуждения учителя переключаются на собственные разногласия. Автор фильма ставит вопрос о том, что общество неоправданно ожидает от учителей решения тех проблем, которые не может решить самостоятельно дома, в семье (Kegel, 2005).

Тем же вопросом задается автор фильма «Фрау Мюллер должна уйти» (2015), где родители «сложных» детей младших классов приходят в школу с единственным намерением - убедить учителя отдать класс другому педагогу, и они абсолютно уверенны, что это и есть единственно правильное решение их проблем. Отношение к школе как сфере 
услуг четко просматривается в реплике педагога: «Я служащая на службе обществу, но не обслуга». В финале сюжета родители кардинально меняют свое мнение и уговаривают Мюллер оставить классное руководство за собой. Получив «вотум доверия своему педагогическому опыту и мастерству», учительница дает согласие, а родители получают импульс к осознанию имеющихся проблем и возможность их решения.

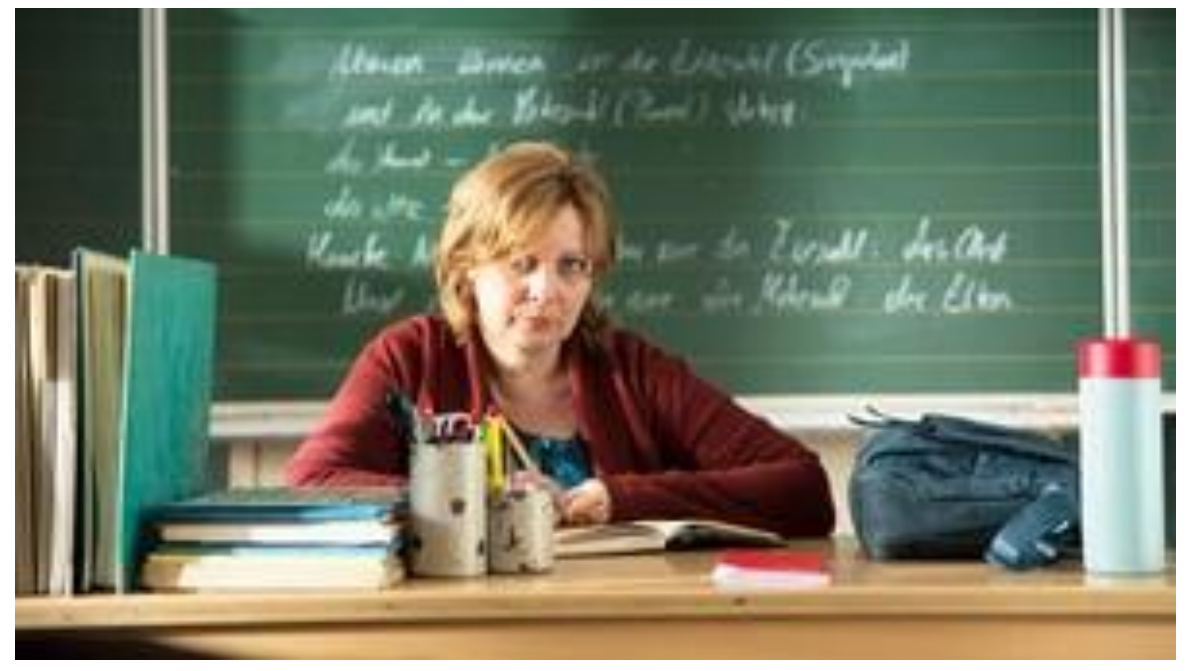

Рис. 5. Кадр из фильма «Фрау Мюллер должна уйти» (2015)

В ходе исследований современных медиатекстов Г. Хелмес пришел к выводу, что теле/кинофильмы о школе обречены на успех (Helmes, Rinke, 2016). Подтверждением тому может служить коммерческий успех картины Б. Дагтекина «Зачетный препод», ставшей лидером проката 2013 года в Германии. Фильм был неоднозначно оценен критиками, однако, среди положительных моментов было отмечено успешное решение режиссера перенести на экран немецкий молодежный язык, в точности воспроизвести сленг и манеры речи современных немецких подростков (Uslar, 2013). Комедийный сюжет нашел продолжение в одноименных фильмах 2015 и 2018 годов, но, по оценкам критиков, каждая последующая версия была хуже предыдущей.

\section{4. Результаты}

Исторический контекст (доминирующие понятия: «медийные агентства», «категории медиа/медиатекстов», «медийные репрезентации» $u$ «медийные аудитории»). а) особенности исторического периода создания медиатекстов, условия рынка, которые способствовали замыслу, процессу создания медиатекстов, степень влияния событий того времени на медиатексты.

После второй мировой войны главные мощности довоенного кинопроизводства сосредоточились в советской зоне оккупации - студия УФА в Бабельсберге. В западной зоне центрами кинопроизводства стали Мюнхен и Гамбург. В мае 1946 года в Потсдаме была учреждена киностудия ДЕФА. В западной зоне союзники проводили политику декартелезации. К середине 1950-х кампании УФА и Бавария контролировали около 6о \% студийных мощностей. В 1960-е изменился подход к финансированию киноиндустрии, были разработаны закон (Filmförderungsgesetz) и соответствующие программы поддержки национального кинематографа, в том числе начинающих режиссеров (Kuratorium junger deutscher Film), создан фонд поддержки кино (Filmförderungsanstalt).

Расцвет «нового кино» в Германии пришелся на 1970-е годы, новый толчок развитию кино придало сотрудничество с телевидением, а именно, инвестирование телекомпаний в кинопроизводство. Международную популярность немецкое кино получило в конце 1990-х с выходом в свет «Беги, Лола, беги» Т. Тыквера, и с тех пор занимает почетное место среди других кинематографий мира. 
b) как знание реальных исторических событий конкретного периода помогает пониманию данных медиатекстов, примеры исторических ссылок в данных медиатекстах.

Осведомленность в части исторических событий рассматриваемого периода безусловно помогает понять отсыл автора кинофильма к историческим и культурным реалиям.

Так, в фильме «Я слон, мадам» (1969) отдельные сцены четко соотносятся с протестным движением школьников против повышения транспортных тарифов в Бремене в январе 1968 года. Подростки сели на трамвайные рельсы и заблокировали движение транспорта, инициатива школьников была поддержана профсоюзными организациями крупных предприятий города. Правительство земли Бремен было вынуждено пойти на уступки и снизить тарифы. Тогда в городе еще не было университета, и школьники стали ведущей силой внепарламентской оппозиции. В фильме, обращаясь к правящим кругам города, учитель немецкого языка Г. Немитц анализирует причины протеста: «Под Вашим руководством, дамы и господа, не хватает школ, не хватает учителей, ... не хватает любви... Предметом недовольства детей являются отнюдь не цены на трамвайные билеты. Дети предметом протеста выбрали деньги только потому, что это единственный понятный Вам язык».

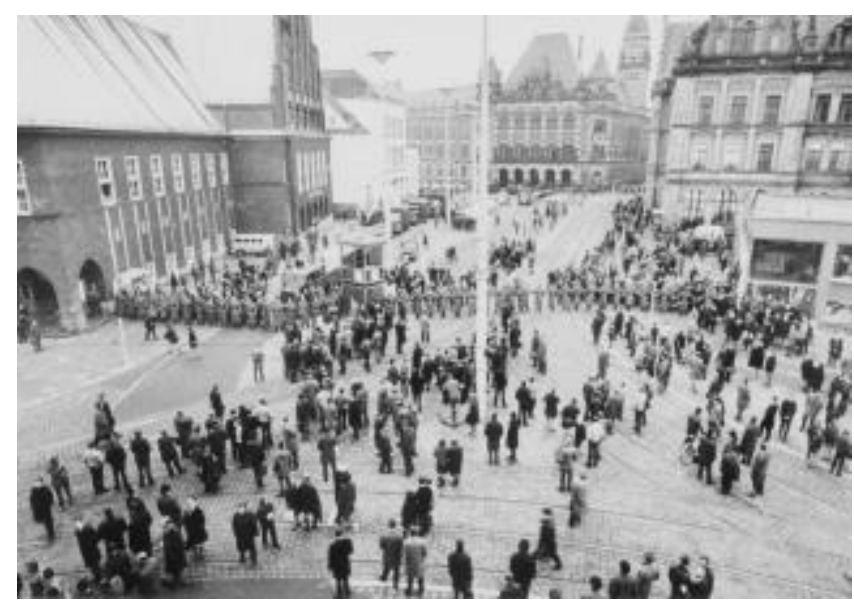

Рис. 6. Кадр из документальной хроники

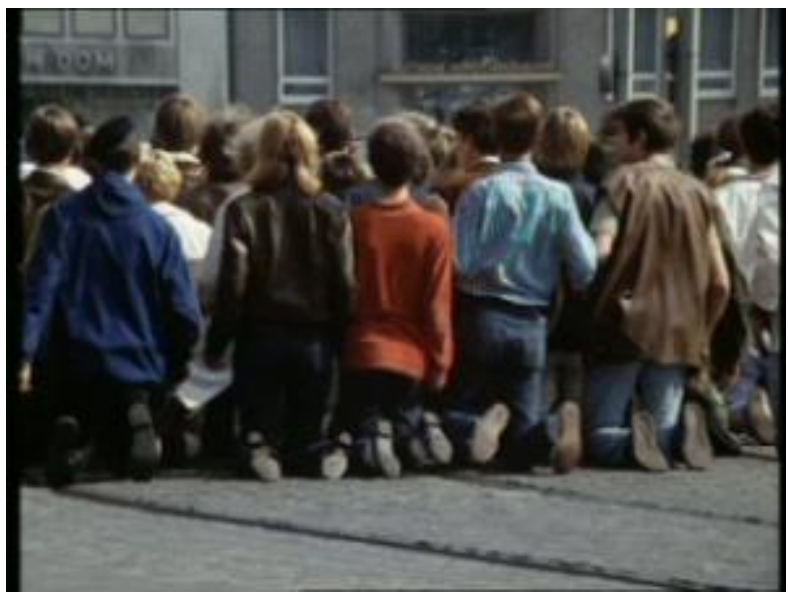

Рис.7. Кадр из фильма «Я слон, мадам» (1969)

2. Социокультурный, идеологический, мировоззренческий, религиозный контекст (доминирующие понятия: «медийные агентства», "категории медиа/медиатекстов», «медийные репрезентации» и «медийная аудитория»).

а) идеология, направления, цели, задачи, мировоззрение, концепции авторов даннъх медиатекстов в социокультурном контексте; идеология, культура мира, изображенного в медиатекстах.

Фильмы послевоенного периода строились на кинематографических традициях Веймарской республики. Сюжеты кинофильмов о школе периода Нового немецкого кино обусловило протестное движение школьников и студентов 1960-х, сложившееся во многом под влиянием Франкфуртской философской школы. Движение в целом было направлено против любых форм авторитаризма, осуждало приход к власти в ФРГ «поколения палачей», боролось с лицемерной сексуальной моралью 1950-х. Современный немецкий кинематограф транслирует четкую установку молодежи на поиск себя, своего места в жизни и обществе.

b) мировоззрение персонажей «цкольного и студенческого мира», изображенного в медиатекстах

В послевоенных фильмах о школе демонстрировались картины идеальных взаимоотношений педагогов и учащихся, построенных на взаимном уважении. «Я у них многому научился...» - признает учитель Зайдель в фильме «Догматик» (1958). В конце 
фильма школьники как один вытягиваются в струнку, приветствуя учителя и тем самым выражая глубокое искреннее уважение и признание авторитета.

В игровых фильмах Нового немецкого кино напротив показано противостояние, абсолютное неприятие, а то и открытый протест школьников в отношении учителей и школьной системы. Главный герой - зачастую равнодушный циничный наблюдатель (Тёрлесс в «Молодой Тёрлесс», 1966) или провокатор (Рул в «Я слон, мадам», 1969), которые противопоставляют себя общей массе сверстников-гимназистов и педагогов, обществу в целом.

В современном кино поднимается проблема не нужных, ни учителям ни родителям детей, живущих без цели и идеологии, в отсутствие морали и ценностей («Волна», 2008; «Зачетный препод», 2013, 2015, 2017). У молодежи нет особого пиетета перед старшим поколением, подростки общаются с учителями свободно, на равных. «Продвинутые» учителя позволяют обращаться к себе на «ты» («Волна», 2008; «Учительница», 2011).

3. Структура и приемы повествования в данных медиатекстах (доминирующие понятия: «категории медиа/медиатекстов», «медийные технологии», «языки медиа», «медийные репрезентации»)

В течение рассматриваемого периода кинематограф шагнул от черно-белого к цветному кино. Схематично структуру, сюжет, репрезентативность, этику, особенности жанровой модификации, иконографии, характеры персонажей медиатекстов школьной тематики в кинематографе рассматриваемого периода с 1945 по 2018 годы можно представить так:

а) место и время действия медиатекстов

С 1960 года на смену закрытым мужским и женским гимназиям («Догматик» 1958; «Летающий класс» 1954; «Взрослеющая молодежь» (1931/1955); «Девушки в униформе» (1931/1958); «Молодой Тёрлесс», 1966) пришли единые школы в ГДР и интегрированные общие школы в ФРГ. В современной Германии по составу учащихся школы общие, обеспечены качественным оборудованием и предоставляют широкие возможности для занятий спортом.

b) характерная для данных медиатекстов обстановка, предметы быта:

Послевоенный период - классные комнаты обставлены аскетично, ничего лишнего: школьные скамьи, на возвышении учительский стол, доска, атрибуты учебного процесса: глобус, карты и пр. С течением времени и до наших дней мало, что изменилось: длинные однотонные школьные коридоры казенных образовательных учреждений, все те же непримечательные аудитории, разве что, учительский стол располагается на одном уровне с ученическими партами.

с) Жанровые модификации школьно-вузовской тематики:

Тема школы в немецком кинематографе в период с 1945 по 2018 годы представлена в полном разнообразии жанров: драма («Я слон, мадам», 1969; «Волна», 2008; «Учительница», 2011), трагикомедия («Догматик», 1958; «Такси до туалета», 1980), триллер («Отстранённый от дел», 1980), комедия («Огненные клещи», 1970; «Йонас», 2012; «Зачетный препод», 2013, 2015 и 2017).

d) (стереотипные) приемы изображения действительности, типология персонажей (черты характера, одежда, телосложение, лексика, мимика, жесты персонажей, присутствие или отсутствие стереотипной манеры репрезентации персонажей в данных медиатекстах).

Можно выделить несколько типичных образов учителя в кинолентах послевоенного периода. Учитель-наставник, уважаемый учениками, понимающий, мудрый, прозорливый директор гимназии Бродерзен в фильме «Взрослеющая молодежь» (1955), Юстутс в «Летающем классе» (1954). Учитель - «маленький человек», способный мало по малу, шаг за шагом спровоцировать серьезные изменения в обществе, например, Зайдель невысокий, худощавый, внешне ранимый и миролюбивый (костюм, галстук, очки, шляпа, трость) в «Догматике» (1958) или Йоахим Хофер в «Завуче Хофере» (1975).

Во времена разделенной Германии на смену догматикам пришли такие карикатурные персонажи, как учителя Грей и Бёммель, а также директор гимназии Кнауер в «Огненных клещах» (1970). Помимо «правильного» учителя (Браш в фильме «Отстранённый от дел», 
1980) появился любимый учащимися учитель с нетрадиционной ориентацией (Франк в «Такси до туалета», 1980).

В современном кинематографе объединенной Германии сформировался комедийный тип учителя-друга, сотоварища (Зеки Мюллер в «Зачетном преподе», 2013, 2015, 2017). В драмах учителя - это зачастую одинокие люди с неудавшейся личной жизнью, не умеющие сочетать семью и работу и отдающие предпочтение последней в силу личных убеждений (Штефан Фольмер в «Учителе», 2012) или сложившихся обстоятельств (Андреа Либнитц в «Учительнице», 2011).

f) существенное изменение в жизни персонажей медиатекстов и возникшая проблема (нарушение привычной жизни):

В кинолентах послевоенного периода ставилась проблема выбора между «уличной романтикой» и «получением образования» («Догматик», 1958). Учитель дает шанс исправиться ученику, сделавшему однажды неправильный выбор («Грязный ангел» / «Der schmutzige Engel», 1958). Режиссеры кинофильмов эпохи Нового немецкого кино обозначили стремление молодежи противопоставить себя социуму и в качестве решения проблемы предлагали вариант, когда общество «выдавливает» тех, кто не хочет в него интегрироваться как, например, гимназисты Тёрлесс и Рул, которых исключают из гимназии. В современном кино школьники предпринимают попытки преобразовать социальное пространство вокруг себя: изменить свое бытие («Волна», 2008), жизнь других людей («Инстинкт игрока», 2013). Эти попытки зачастую оборачиваются трагедией.

\section{5. Заключение}

Кинематограф на тему школы в послевоенный период можно охарактеризовать как инструмент улучшения социального климата в обществе, поскольку возврат к педагогическим традициям Веймарской республики выглядит как попытка создания желаемого идеального образа взаимоотношений ученика и учителя, попытка сгладить острые проблемы подрастающего в послевоенной побежденной Германии поколения. Идеальный педагог - это взрослый, которому дети могут доверять.

В период разделенной Германии фильмы о школе отражают острые социальные проблемы. Проблемы непонимания поколений отцов и детей, поиск возможностей рассчитаться с нацистским прошлым за преступления против человечества путем их осознания и осуждения. В кино демонстрируются мятежные настроения - как в отношении авторитарной педагогики, так и лицемерному отношению к сексуальной морали.

В современных фильмах учителя - прежде всего люди, обыватели, со своими личными заботами и чаяниями, переживающие моменты успеха и неудач.

\section{6. Благодарности}

Статья написана в рамках исследования при финансовой поддержке гранта Российского научного фонда (РНФ). Проект № 17-18-01001 «Школа и вуз в зеркале советских, российских и западных аудиовизуальных медиатекстов», выполняемый в Ростовском государственном экономическом университете.

\section{Литература}

Блюменберг, 1981 - Блюменберг Х.К. В долине мертвых глаз. Заметки к новым фильмам из Германии // Cineticle. Интернет-журнал об авторском кино. № 24. [Электронный ресурс]. URL: http://cineticle.com/texts/1631-hans-christoph-blumenberg-newgerman-cinema.html (дата обращения: 05.06.2018).

Гожанская, 2006 - Гожанская И.В. Кино как объект культурологического исследования: Автореф. дисс. ... канд. культур.. Саратов, 2006. 166 с.

Мкртычева, 2012 - Мкртычева М.С. Кино как объект социологического изучения: возможности и перспективы // Теория и практика общественного развития. 2012. № 12 [Электронный pecypc]. URL: https://cyberleninka.ru/article/n/kino-kak-predmet-sotsiologi cheskogo-izucheniya-vozmozhnosti-i-perspektivy (дата обращения: 05.06.2018). 
Сумароков, 2017- Сумароков A. Новое немецкое кино: точка эмпатии // Postcriticism. 27 декабря 2017. [Электронный ресурс]. URL: http://postcriticism.ru/terra-incognita-novoenemetskoe-kino/(дата обращения: 05.06.2018).

Федоров, 2007 - Федоров А.B. Герменевтический анализ на медиаобразовательных занятиях в студенческой аудитории // Инновационные образовательные технологии. 2007. № 3 (11). С. 56-72.

Федоров, 2013 - Федоров А.B. «Маленький школьный оркестр»: опыт герменевтического анализа медиатекста на занятиях в студенческой аудитории // Медиаобразование. 2013. № 3. С. 48-58.

Юдин, 2017 - Юдин К.А. Х. Рюманн и Г. Фрёбе - классики немецкого кинематографа XX в. // Вестник Ивановского государственного университета. Серия: гуманитарные науки. 2017. Вып. 4. История. С. 25-37.

Blumenberg, 1975 - Blumenberg, H.C. Politik der kleinen Spuren // Die Zeit. № 13/1975 [Электронный pecypc]. URL: https://www.zeit.de/1975/13/politik-der-kleinen-spuren (дата обращения: 05.06.2018).

Brockmann, 2010 - Brockmann, S.A. Critical History of German Film. Camden House, 2010. $522 \mathrm{p}$.

Frank, 2017 - Frank, S.M. Wiedersehen im Wirtschaftswunder: Remakes von Filmen aus der Zeit des Nationalsozialismus in der Bundesrepublik 1949-1963. V\&R unipress GmbH, Göttingen, 2017. $451 \mathrm{p}$.

Graff, 2010 - Graff, B. Er war ein Elefant, Madame // Süddeutsche Zeitung. 17. Mai 2010. [Electronic resource]. URL: http://www.sueddeutsche.de/kultur/zum-tod-von-peter-zadek-erwar-ein-elefant-madame-1.159038 (дата обращения: 05.06.2018).

Grimme, 2008 - Grimme 2008. Preispublikation Grimme-Preis. Guten Morgen, Herr Grote (ARD/WDR). [Electronic resource]. URL: http://www.grimme-preis.de/archiv/2008/preistraeger/ $\mathrm{p} / \mathrm{d} /$ guten-morgen-herr-grothe-ardwdr/(дата обращения: 05.06.2018).

Helmes, 2016 - Helmes, G.. Rinke, G. Gescheit, gescheiter, gescheitert? Das zeitgenössische Bild von Schule und Lehrern in Literatur und Medien. Igel Verlag, Hamburg. 288 p.

Kegel, 2005 - Kegel, Sa. Die neun Geschworenen. / Frankfurter Allgemeine. 4. Februar 2005. [Electronic resource]. URL: http://www.faz.net/aktuell/feuilleton/kino/fernsehen-dieneun-geschworenen-1214317.html (дата обращения: 05.06.2018).

Knight, 2007 - Knight, J. New German Cinema // Introduction to Film Studies / Nelmes, J., Mensch, A.. Routledge, 2007. 512 p.

Koch, 1987 - Koch, F. Schule im Kino: Autorität und Erziehung. Vom "Blauen Engel” bis zur "Feuerzangenbowle". Weinheim; Basel: Beltz, 1987. 240 p.

Körner, 2001 - Körner, T. Der kleine Mann als Star: Heinz Rühmann und seine Filme der 50er Jahre. Campus Verlag, Frankfurt/Main, 2001. 424 p.

Mai, 2006 - Mai M., Winter R. Kino, Gesellschaft und soziale Wirklichkeit: Zum Verhältnis von Soziologie und Film // Das Kino der Gesellschaft - die Gesellschaft des Kino. Interdisziplinäre Positionen, Analysen und Zugänge / Hrsg. von M. Mai, R.Winter. Köln, 2006. pp. 7-23.

Piroth, 2004 - Piroth, N. Gemeindepädagogische Möglichkeitsräume biographischen Lernens. LIT Verlag, Münster, 2004. $331 \mathrm{p}$.

Probst, 2008 - Probst, M. Macht durch Handeln! / Die Zeit. 13. März 2008. № 12 https://www.zeit.de/2008/12/Film-Die-Welle (дата обращения: 05.06.2018).

Roschy, 2008 - Roschy, Bt. Schule, Lehren und Lernen im Film. 2008 https://www.kinofenster.de/filme/filmdesmonats/schule_lehren_und_lernen_im_film/_(дата обращения: 05.06.2018).

Schelsky, 1957- Schelsky, H. Die skeptische Generation. Eine Soziologie der deutschen Jugend. Eugen Diederichs Verlag: Düsseldorf/Köln, 1957.523 p.

Uslar, 2013 - Uslar, M. Geisterkranker! / Die Zeit. 5. Dezember 2013. № 50 https://www.zeit.de/2013/50/teenagerkomoedie-fack-ju-goehte-sprachkritik (дата обращения: 05.06.2018).

Watson, 1996 - Watson, W.S. Understanding Rainer Werner Fassbinder: Film as Private and Public Art. University of South Carolina Press, 1996. 341 p. 
Wunderlich, 2009 - Wunderlich, D. Folker Schlöndorff. Der junge Törless. / Buchtipps \& Filmtipps [Electronic resource]. URL: http://www.dieterwunderlich.de/Schloendorff_ Toerless.htm\#kritik (дата обращения: 05.06.2018).

\section{References}

Blumenberg, 1975 - Blumenberg, H.C. (1975). Politik der kleinen Spuren // Die Zeit. № 13/1975. [Electronic resource]. URL: https://www.zeit.de/1975/13/politik-der-kleinen-spuren (accessed: 05.06.2018).

Blumenberg, 1981 - Blumenberg H.K. (1981). V doline mertvyh glaz. Zametki k novim filmam iz Germanii [In the valley of dead eyes. Notes to new films from Germany]. Cineticle. № 24. [Electronic resource]. URL: http://cineticle.com/texts/1631-hans-christoph-blumenberg-newgerman-cinema.html (accessed: 05.06.2018). [in Russian]

Brockmann, 2010 - Brockmann, S.A. (2010). Critical History of German Film. Camden House, $522 \mathrm{p}$.

Fedorov, 2007 - Fedorov A.V. (2007). Germenevticheski analysis na mediaobrazovatelnyh zanyatiyah $\mathrm{v}$ studencheskoi auditorii [Hermeneutic analysis in media education classes for university students]. Innovazionnye obrazovatelye technologii, № 3 (11). pp. 56-72. [in Russian]

Fedorov, 2013 - Fedorov A.V. (2013). "Malenki shkolny orkestr": opit germenevticheskogo analiza mediateksta na zanyatiah v studencheskoi auditorii ["Little School Orchestra": a hermeneutic analysis of the media text by university students] Mediaobrazovanie. № 3. pp. 4858. [in Russian]

Frank, 2017 - Frank, S.M. (2017). Wiedersehen im Wirtschaftswunder: Remakes von Filmen aus der Zeit des Nationalsozialismus in der Bundesrepublik 1949-1963. V\&R unipress GmbH, Göttingen, $451 \mathrm{p}$.

Gozhanskaya, 2006 - Gozhanskaya I.V. (2006). Kino kak objekt kulturologicheskogo issledovaniya [Film as an object of cultural studies]. Author's abstract of Ph.D. dissertation. Saratov, 166 p. [in Russian]

Graff, 2010 - Graff, B. (2010). Er war ein Elefant, Madame // Süddeutsche Zeitung. 17. Mai 2010. [Electronic resource]. URL: http://www.sueddeutsche.de/kultur/zum-tod-von-peterzadek-er-war-ein-elefant-madame-1.159038 (accessed: 05.06.2018).

Grimme, 2008 - Grimme 2008. Preispublikation Grimme-Preis. Guten Morgen, Herr Grote (ARD/WDR). [Electronic resource]. URL: http://www.grimme-preis.de/archiv/2008/ preistraeger/p/d/guten-morgen-herr-grothe-ardwdr/ (accessed: 05.06.2018).

Helmes, 2016 - Helmes, G., Rinke, G. (2016). Gescheit, gescheiter, gescheitert? Das zeitgenössische Bild von Schule und Lehrern in Literatur und Medien. Igel Verlag, Hamburg. 288 p.

Kegel, 2005 - Kegel, Sa. (2005). Die neun Geschworenen. / Frankfurter Allgemeine. 4. Februar 2005. [Electronic resource]. URL: http://www.faz.net/aktuell/feuilleton/kino/fernsehendie-neun-geschworenen-1214317.html (accessed: 05.06.2018).

Knight, 2007 - Knight, J. (2007). New German Cinema // Introduction to Film Studies / Nelmes, J., Mensch, A. Routledge, 2007. 512 p.

Koch, 1987 - Koch, F. (1987). Schule im Kino: Autorität und Erziehung. Vom "Blauen Engel” bis zur "Feuerzangenbowle". Weinheim; Basel: Beltz, 1987. 240 p.

Körner, 2001 - Körner, T. (2001). Der kleine Mann als Star: Heinz Rühmann und seine Filme der 5oer Jahre. Campus Verlag, Frankfurt/Main, 2001. 424 p.

Mai, 2006 - Mai M., Winter R. (2006). Kino, Gesellschaft und soziale Wirklichkeit: Zum Verhältnis von Soziologie und Film // Das Kino der Gesellschaft - die Gesellschaft des Kino. Interdisziplinäre Positionen, Analysen und Zugänge / Hrsg. von M. Mai, R.Winter. Köln, 2006. pp. 7-23.

Mkrtycheva, 2012 - Mkrtycheva M.S. (2012). Kino kak predmet sotsiologicheskogo izucheniya: vozmozhnosti i perspektivy [Film as an object of social studies: ways and prospects Teoria $i$ praktika obschestvennogo razvitiya. № 12 . [Electronic resource]. URL: https://cyberleninka.ru/article/n/kino-kak-predmet-sotsiologicheskogo-izucheniyavozmozhnosti-i-perspektivy (accessed: 05.06.2018). [in Russian]

Piroth, 2004 - Piroth, N. (2004). Gemeindepädagogische Möglichkeitsräume biographischen Lernens. LIT Verlag, Münster, 2004. 331 p. 
Probst, 2008 - Probst, M. (2008). Macht durch Handeln! / Die Zeit. 13. März 2008. № 12 [Electronic resource]. URL: https://www.zeit.de/2008/12/Film-Die-Welle (accessed: 05.06.2018).

Roschy, 2008 - Roschy, Bt. (2008). Schule, Lehren und Lernen im Film. 2008 [Electronic resource]. URL: https://www.kinofenster.de/filme/filmdesmonats/schule_lehren_und_lernen _im_film/ (accessed: 05.06.2018).

Schelsky, 1957- Schelsky, H. (1957). Die skeptische Generation. Eine Soziologie der deutschen Jugend. Eugen Diederichs Verlag: Düsseldorf/Köln, 523 p.

Sumarokov, 2017- Sumarokov A. (2017). Novoe nemetskoe kino: tochka empatii [New German film: point of empathy] Postcriticism. [Electronic resource]. URL: http://postcriticism.ru/terra-incognita-novoe-nemetskoe-kino/ $\quad$ (accessed: $\quad$ 05.06.2018). [in Russian]

Uslar, 2013 - Uslar, M. (2013). Geisterkranker! / Die Zeit. 5. Dezember 2013. № 50 [Electronic resource]. URL: https://www.zeit.de/2013/50/teenagerkomoedie-fack-ju-goehtesprachkritik (accessed: 05.06.2018).

Watson, 1996 - Watson, W.S. (1996). Understanding Rainer Werner Fassbinder: Film as Private and Public Art. University of South Carolina Press, 1996. 341 p.

Wunderlich, 2009 - Wunderlich, D. (2009). Folker Schlöndorff. Der junge Törless. / Buchtipps \& Filmtipps [Electronic resource]. URL: http://www.dieterwunderlich.de/Schloendorff_ Toerless.htm\#kritik (accessed: 05.06.2018).

Yudin, 2017 - Yudin K.A. (2017). H.Rühmann i G.Fröbe - klassiki nemezkogo kinematografa XX v. [H. Rühmann and Karl Gerhart "Gert" Fröbe - the classics of German cinema]. Vestnik Ivanovkogo gosudarstvennogo universiteta. Is. 4. pp. 25-37. [in Russian]

\title{
Герменевтический анализ немецкоязычных аудиовизуальных текстов на тему школы (1945-2018)
}

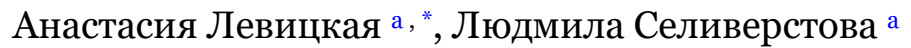 \\ а Таганрогский институт управления и экономики, Российская Федерация
}

Аннотация. Статья посвящена анализу немецкоязычных аудиовизуальных медиатекстов на школьную тематику, вышедших на экран в Германии в период с окончания второй мировой войны до настоящего времени методом сравнительного герменевтического анализа. В ходе анализа удалось выяснить, что в послевоенный период кинематографисты стремились улучшить социальный климат в обществе, вернуться к педагогическим традициям Веймарской республики, создать желаемый идеальный образ взаимоотношений ученика и учителя, пытались сгладить острые проблемы подрастающего в послевоенной побежденной Германии поколения. В роли идеального педагога рисовался взрослый, которому дети могут доверять.

В период разделенной Германии фильмы о школе отражали острые социальные проблемы: проблемы непонимания поколений отцов и детей, поиск возможностей рассчитаться с нацистским прошлым за преступления против человечества путем их осознания и осуждения. В кино демонстрировались мятежные настроения как по отношению к авторитарной педагогике, так и лицемерной сексуальной морали.

Современный немецкий кинематограф транслирует четкую установку молодежи на поиск себя, своего места в жизни и обществе. Учителя - прежде всего люди, обыватели, со своими личными заботами и чаяниями, переживающие моменты успеха и неудач.

Ключевые слова: герменевтика, анализ, медиатекст, медиакритика, фильм, школьники, медиаграмотность, медиаобразование, Германия.

\footnotetext{
* Корреспондирующий автор

Адреса электронной почты: a.levitskaya@tmei.ru (А. Левицкая), l.seliverstova@tmei.ru (Л. Селиверстова)
} 